\title{
Is open peer review, a growing trend in scholarly publishing, a double-edged sword?
}

\author{
Joo-Young Park, DDS, $\mathrm{PhD}^{1,2}$ \\ Section Editor of JKAOMS \\ ${ }^{\prime}$ Department of Oral and Maxillofacial Surgery, School of Dentistry, Seoul National University, \\ ${ }^{2}$ Seoul National University Dental Hospital, Seoul, Korea
}

Peer review has been a formal part of scientific communication since the first scientific journals appeared more than 300 years ago. The Philosophical Transactions of the Royal Society, a British scientific journal first published in 1665, is thought to be the beginning of the formal peer review process $^{1,2}$. The Journal of the Korean Association of Oral and Maxillofacial Surgeons (JKAOMS) has also used peer review for scientific communication and discussion since its launch in 1975 by handwritten letters, emails, and most recently, via an online submission system.

Peer review is the evaluation of work by one or more people with similar competencies as the producers of the work ${ }^{2}$. This review functions as a test or regulation by qualified professionals within the relevant field, which leads to improved quality of published research and networking within research communities. It remains the only widely accepted method for research validation and has continued successfully with relatively few changes ${ }^{3,4}$. Dr. Lachmann has described peer review as being to science what democracy is to politics. It is not the most efficient mechanism, but it is the least corruptible ${ }^{5}$.

However, the reviewers and editors of several journals have raised the issue of transparency of peer review process and have sought to change the current procedures for anonymous peer review ${ }^{6,7}$. Three types of peer review, single-, double-

\footnotetext{
Joo-Young Park

Department of Oral and Maxillofacial Surgery, School of Dentistry, Seoul National University, 101 Daehak-ro, Jongno-gu, Seoul 03080, Korea TEL: +82-2-2072-4498 FAX: +82-2-766-4948

E-mail:bbyoung1@snu.ac.kr

ORCID: https://orcid.org/0000-0002-0333-6349

(a) This is an open-access article distributed under the terms of the Creative Commons Attribution Non-Commercial License (http://creativecommons.org/ licenses/by-nc/4.0/), which permits unrestricted non-commercial use, distribution, and reproduction in any medium, provided the original work is properly cited. Copyright (C) 2020 The Korean Association of Oral and Maxillofacial Surgeons. All rights reserved.
}

and triple-blind reviews (Table 1), are the most commonly used review processes and have fundamental issues related to anonymity ${ }^{7,8}$. For example, it is typically possible for the reviewers to identify the authors, which results in impartial decisions, delayed publication, and unnecessarily harsh criticism. Therefore, open peer review, peer review where authors' and reviewers' identities are disclosed to one another, is a growing trend in scholarly publishing. ${ }^{8}$. Several subtypes of open peer review have been suggested, the most common type being when both the reviewer and author are known to each other during the peer review process. Some journals publish reviewers' names on the article page, or peer review reports alongside the article, whether signed or anonymous. Another type of open peer review is publication of peer review reports (signed or anonymous) together with authors' and editors' responses alongside the article.

Despite the expectations of open peer review preventing malicious comments, plagiarism, and encouraging honest open responses, the majority of referees believed it would achieve the opposite effect and promote less open and less honest reports ${ }^{8,9}$. Many felt that anonymity was key to reviewing to avoid politics. Some reviewers said their opinions would be less likely to be direct and honest if their comments and identities were open to the public'. It was also believed that a junior researcher reviewing an eminent scientist's work would be less likely to be honest for fear of affecting their own career or funding opportunities. Open reviewing is practiced in the British Medical Journal for example, and in a study conducted by the journal itself, it recognized there was no discernable improvement in the quality of reviewing; importantly, open reviewing significantly increased the likelihood of reviewers declining to review ${ }^{10}$.

Therefore, open peer review, a new trend in scholarly publishing, could have limitation with regard to global scientific journal policy. Rather than abandoning blind peer review, we 
Table 1. Types of peer review and points to consider regarding each type

\begin{tabular}{|c|c|c|c|}
\hline Type & Description & Advantages & Disadvantages \\
\hline Single-blind review & $\begin{array}{l}\text { The names of the reviewers are } \\
\text { hidden from the author. }\end{array}$ & & $\begin{array}{l}\text { Reviewer anonymity allows for } \\
\text { impartial decisions. } \\
\text { Reviewers may use their } \\
\text { anonymity as a justification for } \\
\text { being unnecessarily critical or } \\
\text { harsh when commenting on the } \\
\text { authors' work. }\end{array}$ \\
\hline Double-blind review & $\begin{array}{l}\text { Both the reviewer and the author } \\
\text { are anonymous. }\end{array}$ & $\begin{array}{l}\text { Author anonymity limits reviewer } \\
\text { bias based on an author's gender, } \\
\text { country of origin, academic } \\
\text { status, or previous publication } \\
\text { history. }\end{array}$ & $\begin{array}{l}\text { Reviewers can often identify the } \\
\text { author through their writing style, } \\
\text { subject matter, or self-citation - } \\
\text { it is difficult to guarantee total } \\
\text { author anonymity. }\end{array}$ \\
\hline Triple-blind review & $\begin{array}{l}\text { Reviewers are anonymous and } \\
\text { the author's identity is unknown } \\
\text { to both the reviewers and the } \\
\text { editor. }\end{array}$ & $\begin{array}{l}\text { This can minimize any potential } \\
\text { bias towards the author(s). }\end{array}$ & $\begin{array}{l}\text { The complexities involved with } \\
\text { anonymizing articles/authors to } \\
\text { this level are considerable. } \\
\text { It is still difficult to guarantee total } \\
\text { author anonymity. }\end{array}$ \\
\hline Open review & $\begin{array}{l}\text { A term for many different models } \\
\text { aiming at greater transparency } \\
\text { during and after the peer review } \\
\text { process. } \\
\text { The most common subtype is when } \\
\text { both the reviewer and author are } \\
\text { known to each other during the } \\
\text { peer review process. }\end{array}$ & $\begin{array}{l}\text { Many believe this is the best way } \\
\text { to improve transparency of the } \\
\text { review process. }\end{array}$ & $\begin{array}{l}\text { Others see open review as a } \\
\text { less honest process, in which } \\
\text { politeness or fear of punishment } \\
\text { may cause a reviewer to hesitate } \\
\text { or tone down criticism. }\end{array}$ \\
\hline
\end{tabular}

Joo-Young Park: Is open peer review, a growing trend in scholarly publishing, a double-edged sword? J Korean Assoc Oral Maxillofac Surg 2020

should seek to improve its transparency, using the following processes: 1) anonymity can be maintained; 2) multiple reviewers should be involved; 3 ) the duration of the review process should be announced ahead; 4) how the final decision is made should be openly understood by the authors and reviewers; 5) rejection rates of the journal should be publicly available; and 6) feedback should be given to reviewers. Editors, referees, and the readers of JKAOMS should consider the pros and cons of ongoing changes in scholarly publishing, especially the current trend in open peer review, as we work toward improving fairness and transparency in scientific publications.

\section{Conflict of Interest}

No potential conflict of interest relevant to this article was reported.

\section{References}

1. Zuckerman H, Merton RK. Patterns of evaluation in science: institutionalisation, structure and functions of the referee system. Minerva 1971;9:66-100. https://doi.org/10.1007/BF01553188

2. Weller AC. Editorial peer review: its strengths and weaknesses. Medford: Information Today; 2001:1-3.
3. Mulligan A. Is peer review in crisis? Perspect Publ 2004;2:1-6.

4. Publishing Research Consortium. Publishing Research Consortium peer review survey 2015. Bristol: Mark Ware Consulting; 2016:2-4.

5. Lachmann P. The research integrity initiative: progress report. In: White C, ed. The COPE report 2002: annual report of the Committee on Publication Ethics. London: BMJ Books; 2002:11.

6. Justice AC, Cho MK, Winker MA, Berlin JA, Rennie D. Does masking author identity improve peer review quality? A randomized controlled trial. PEER investigators. JAMA 1998;280:240-2. https://doi.org/10.1001/jama.280.3.240

7. Fennell C, Corney A, Ash E. Transparency - the key to trust in peer review [Internet]. Amsterdam: Elsevier Connect [cited 2017 Jul 12]. Available from: https://www.elsevier.com/connect/transparency-the-key-to-trust-in-peer-review.

8. Ford E. Open peer review at four STEM journals: an observational overview. F1000Res 2015;4:6. https://doi.org/10.12688/f1000research.6005.2

9. Mehmani B. Is open peer review the way forward? [Internet]. Amsterdam: Elsevier Connect [cited 2016 Sep 22]. Available from: https://www.elsevier.com/reviewers-update/story/innovation-inpublishing/is-open-peer-review-the-way-forward.

10. van Rooyen S, Godlee F, Evans S, Black N, Smith R. Effect of open peer review on quality of reviews and on reviewers' recommendations: a randomised trial. BMJ 1999;318:23-7. https://doi. org $/ 10.1136 / \mathrm{bmj} .318 .7175 .23$

How to cite this article: Park JY. Is open peer review, a growing trend in scholarly publishing, a double-edged sword? J Korean Assoc Oral Maxillofac Surg 2020;46:299-300. https://doi.org/10.5125/ jkaoms.2020.46.5.299 